Summer 2016

\title{
The Etymology of Nigger: Resistance, Language, and the Politics of Freedom in the Antebellum North
}

Elizabeth Stordeur Pryor

Smith College

Follow this and additional works at: https://scholarworks.smith.edu/hst_facpubs

Part of the History Commons

\section{Recommended Citation}

Pryor, Elizabeth Stordeur, "The Etymology of Nigger: Resistance, Language, and the Politics of Freedom in the Antebellum North" (2016). History: Faculty Publications, Smith College, Northampton, MA.

https://scholarworks.smith.edu/hst_facpubs/4 


\section{PROJECT MUSE}

The Etymology of Nigger: Resistance, Language, and the Politics of Freedom in the Antebellum North

Elizabeth Stordeur Pryor

Journal of the Early Republic, Volume 36, Number 2, Summer 2016, pp. 203-245 (Article)

Published by University of Pennsylvania Press

DOI: https://doi.org/10.1353/jer.2016.0028

$\Rightarrow$ For additional information about this article https://muse.jhu.edu/article/620987 


\section{The Etymology of Nigger \\ Resistance, Language, and the Politics of Freedom in the Antebellum North}

\section{ELIZABETH STORDEUR PRYOR}

In 1837, Hosea Easton, a black minister from Hartford, Connecticut, was one of the earliest black intellectuals to write about the word "nigger." In several pages, he documented how it was an omnipresent refrain in the streets of the antebellum North, used by whites to terrorize "colored travelers," a term that elite African Americans with the financial ability and personal inclination to travel used to describe themselves. On reflecting upon the ways that the word nigger impacted colored travelers, Easton painted a picture of an urban landscape in which "little urchins of Christian villagers" pestered black men and women as they passed. He said white parents and teachers used the

Elizabeth Stordeur Pryor is an assistant professor of history at Smith College. Thanks to UNC Press. From Colored Travelers: Mobility and the Fight for Citizenship before the Civil War by Elizabeth Stordeur Pryor. Copyright (C) 2016 by Elizabeth Stordeur Pryor. Published by the University of North Carolina Press. Used by permission of the publisher. Smith College gave me the necessary time to consider the ideas in this essay. For reading (sometimes multiple) drafts, talking me through and offering insights, I would like thank Patricia Cline Cohen, Joanne Pope Melish, David Roediger, Dawn Peterson, Barbara Krauthamer, Ted Melillo, Khary Polk, Leslie Alexander, Emily Bernard, Kevin Quashie, Dan Horowitz, Jennifer Guglielmo, Lisa Armstrong, Jeff Ahlman, Josh Birk, Shani Roper, Darcy Buerkle, Cathy Kelly, the anonymous readers from the $\mathcal{F E R}$, and my students at Smith College who share their revelations about "the n-word," as we call it in my classroom, every semester. The oversights in thinking are mine alone. Thank you to the Stordeurs: Jerry, Lilli, and Henry. Also, thank you to my father for inspiring a life-long obsession with the discomforts and meanings of this single word, at first, because he said it all the time, and later, when I was 11, because he decided never to say it again. 
word to instruct children that blacks were deficient, but also to show how their own racial status was precarious. They disciplined white children with stories of nigger boogeymen and promised a child would "have no more credit than a nigger" if she misbehaved. Children absorbed their racial lessons and reacted with open hostility when they saw real black people. White children taunted, "see nigger's thick lipssee his flat nose-nigger eye shine-that slick looking nigger-nigger, where you get so much coat?-that's a nigger priest." As he moved throughout the North, Easton experienced a cacophony of children's voices that "continually infest[ed] the feelings of colored travellers, like the pestiferous breath of young devils," and white adults were "heard to join in the concert." The same year, a white abolitionist concurred and highlighted how whites deployed the word nigger to hamper black mobility, noting that "if a negro walked the street, he was often hailed by men and boys with 'Cuffee - nigger!' or the like."'

1. I call the subjects of this study "colored travelers," a term that antebellum activists used to describe black people who frequently traversed public space and relied on public conveyances. "Colored" is an apt descriptor because black activists in the nineteenth century consciously chose it to signal racial unity. The term appeared at least as early as 1829 when black Bostonian David Walker, one of the most influential activists of the period, harnessed it in the title of his anti-slavery manifesto, Appeal ... to the Coloured Citizens of the World. In 1830, black leaders in New York also used it when they named the Colored Convention movement in order to assert black consensus in the quest for U.S. citizenship. Of course, the term "colored" was not uncomplicated because it also announced class standing. In 1837, when Easton noted that "colored travellers" were under white siege in public space, he was expressing something specific about the travelers' race, their respectability, and their activism. On the use of the word "colored," see the title page of David Walker, Walker's Appeal in Four Articles: Together with a Preamble to the Colored Citizens of the World, but in Particular, and Very Expressly, to Those of the United States of America (1829; repr. Boston, 1830), Sabin Americana, 1500-1926, galenet.galegroup.com/servlet/Sabin, accessed Dec. 21, 2015; Leslie M. Alexander, African or American? Black Identity and Political Activism in New York City, 1784-1861 (Champaign, IL, 2008), 78-83; Patrick Rael, Black Identity and Black Protest in the Antebellum North (Chapel Hill, NC, 2002), 102-107; Hosea Easton, A Treatise on the Intellectual Character and Civil and Political Condition of the Colored People of the U. States: And the Prejudice Exercised Towards Them (Boston, 1837), 40-41. Easton's descriptions of the word nigger, ibid., 40-41. "Remarks of Dr. Blake. On Proposing for Adoption of the Following Resolution in the Young Men's Convention Last Week," The Colored American (New York), Sept. 16, 1837 (emphasis original). Regarding the early education of 
In the antebellum United States, colored travelers were acutely aware that travel at home-not the houses in which they lived, but the streets, towns, and cities they traversed-was fundamentally inhospitable. Going out in public meant confronting the verbal assault "nigger." This single word-nigger-captured the magnitude of anti-black feeling and was unleashed upon free people as they moved through urban space, rode public vehicles, and even ventured abroad. For free African Americans, independent travel within their hometowns and beyond was stressful, dangerous, and sometimes deadly. The ubiquity of the word nigger illuminated the limits of their freedom. Despite the fact that by 1800 Vermont, New Hampshire, and Massachusetts were ostensibly free states and between 1780 and 1804 New York, Connecticut, Rhode Island, Pennsylvania, and New Jersey passed a series of gradual abolition laws to end enslavement, the institution still left an indelible mark in the region. Without the racial control that slavery ensured, anti-black violence increased in the 1820s North. Prior to the 1770s, the labels nigger and slave were interchangeable, each describing an actual social category of involuntary black laborers. As African Americans became free in the North, however, nigger latched on like a shackle. White Americans of all classes and ages hissed out the word, branding free black people as foul smelling, unproductive, licentious, and unfit for self-rule. By the 1820s, blackness, not slavery, marked people of color as occupying a fixed social class. Most significantly, the word nigger became a slur in conversation with black social aspiration. In the early nineteenth century, a small but influential black middle class-a group characterized by education and activism, not necessarily prosperity_-began to defy their prescribed roles as laborers. They asserted their right to equal access to the goods and services designed for public consumption, including entrée into vehicles of transportation, theaters, taverns, and inns. To prevent such freedom of mobility, nigger emerged as a weapon of racial containment, a barometer against which to measure the increasingly rigid boundaries of whiteness and a mechanism used to police and cleanse public space. ${ }^{2}$

white children in the act of taunting African Americans with the use of the word nigger, see also Cora, "Moral: The Story of Poor Jack," in The Liberator (Boston), Apr. 11, 1835; and William Drown to William Lloyd Garrison, "Communications: Colored People of Rhode Island," published in The Liberator (Boston), Oct. 18, 1839.

2. Arthur Zilversmit, The First Emancipation: The Abolition of Slavery in the North (Chicago, 1967). On Connecticut's gradual abolition laws, see David 
Colored travelers such as Hosea Easton, David Walker, Frederick Douglass, J. W. C. Pennington, William Wells Brown, and Harriet Jacobs used the word nigger in their lectures and literary productions to expose and protest the complex relationship they had with the place they called home. An etymology of the word from descriptor to epithet shows how and why black activists designated it a verbal symbol of U.S. racial repression, even as African American laborers continued to use it. Indeed, the word became virulent precisely because black laborers integrated it into their own vocabularies, a practice that is an understudied and overlooked aspect of African American history. In other words, the label carried so much discursive weight because black laborers spoke it, self-identified as such, and by so doing, subverted notions of race and class identity in the United States. In turn, whites disavowed the word's traceable European origins, and by the 1820s largely used it to mock black speech. They placed the onus of black subordination on black people themselves, using African American vernacular to make inequality appear both logical and natural. When the transatlantic abolitionist movement was underway by the 1830 s, black activists unmasked the venomous dialectics of nigger. They elevated the word to epithet, uttering it publicly with reluctance and only to demonstrate the oppressive inequality and political hypocrisy endemic to the country of their birth. ${ }^{3}$

Menschel, "Abolition without Deliverance: The Law of Connecticut Slavery, 1784-1848," Yale Law Fournal 111 (Oct. 2001), 183-222. On New York, see Leslie M. Harris, In the Shadow of Slavery: African Americans in New York City, 1626-1863 (Chicago, 2003), 50-95; and Alexander, African or American, 2-4. Gary B. Nash and Jean R. Soderlund, Freedom By Degrees: Emancipation in Pennsylvania and Its Aftermath (New York, 1991), 76-80. On New Jersey, Paul Finkelman, "Chief Justice Hornblower of New Jersey and the Fugitive Slave Law of 1793," in Slavery and the Law, ed. Paul Finkelman (Madison, WI, 1997), 113-20. Erica Armstrong Dunbar, A Fragile Freedom: African American Women and Emancipation in the Antebellum Gity (New Haven, CT, 2008), 29. On antiblack violence after emancipation in the North, John Wood Sweet, Bodies Politic: Negotiating Race in the American North, 1730-1830 (Philadelphia, 2007), 35455. On emancipation in New England, see Joanne Pope Melish, Disowning Slavery: Gradual Emancipation and "Race" in New England, 1780-1860 (Ithaca, NY, 1998), 84-118. On the meaning of the black middle-class in the antebellum North, see Harris, In The Shadow of Slavery, 8.

3. The work of cultural theorist Raymond Williams informs my thinking about how to define a word as controversial as nigger. Williams argues that people make "explicit and implicit connections" that inform meanings and the definitions are more often than not "inextricably bound up with the problems [the word] was 
A note on the term: In this essay, I have not bracketed the word nigger with quotation marks. It was a point with which I grappled considerably. In part, this is because, as I argue throughout, the violence of the word is directly connected to the fact that when northern whites spoke it, they largely imagined they were quoting black people. Likewise, when black activists later uttered the word themselves, they imagined they were quoting white racists. Therefore, quotation marks would have indicated what was true, that many who spoke the word in the nineteenth century did so reflectively, to emulate the vocabulary of someone else. Yet, in the twenty-first century those same quotation marks are used to set the word nigger apart from other words, to flag it as one that is offensive, a word that no respectable person would dare to speak. Flanking the word in "scare quotes" creates a barrier meant to protect the reader or to signal the squeamishness of the writer who would have chosen any other word if only she or he could. Most significantly, the quotation marks also indicate a presumption. Using them suggests that we all know exactly what this word means. It is my contention, however, that we should not be so sure. For the same reason, although I will never personally speak the word in a public forum, opting instead for the colloquial (and admittedly fraught) phrase, "the n-word," I choose here not to replace the actual word with the popular surrogate because it too supposes an agreed-upon history and understanding, one that I hope this article challenges. ${ }^{4}$

being used to discuss." In the U.S. context, nigger was profoundly tied to ideas about slavery, race, labor, gender, and class. Speaking about the word without considering these factors obscures its real meanings. Raymond Williams, Keywords: A Vocabulary of Culture and Society (New York, 1983), 15. The examination of the word nigger that I undertake in this article would not be possible without the intellectual and often personal reflections of several scholars. These works include Farai Chideya, The Color of Our Future: Race in the 21st Century (New York, 1999), 7-9; Randall L. Kennedy, "Who Can Say 'Nigger'? And Other Considerations," The fournal of Blacks in Higher Education 26 (Winter 19992000), 86-96; Kennedy, Nigger: The Strange Career of a Troublesome Word (New York, 2003); Rael, Black Identity and Black Protest, 91-102; Emily Bernard, "Teaching the N-Word: A Black Professor, An All-White Class, and the Thing Nobody Will Say," American Scholar 74 (Autumn 2005), 46-59; Jabari Asim, The $\mathcal{N}$ Word: Who Can Say It, Who Shouldn't and Why (Boston, 2007).

4. Merrill Perlman, "Scare' Tactics: Quotes around Single Words," Columbia fournalism Review 28 (Jan. 2013), http://www.cjr.org/language_corner/scare _tactics.php, accessed Dec. 20, 2015. 


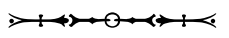

The best place to begin a conversation about the term nigger is in the late 1820 s, a moment when it already reverberated with white belonging and black exile. Yet, to presume the word was always and had only ever been a slur misses the point of its virulence. Instead, it was a word with multiple vantage points, a word whose meanings were complicated by the race and class of the person who spoke it. This is a fact exemplified by a close look at how David Walker used it in his famous 1829 manifesto Appeal . . . to the Coloured Citizens of the World. Walker, a free man of color who penned his abolitionist pamphlet when he lived in Boston, used his writing as a forum to indict U.S. whites for slavery and their demeaning treatment of free people of color in the North. In the scope of his writing, he invoked the word nigger four times, twice in the body of the work and twice in separate footnotes. Walker's most familiar description confirms what modern readers already know. The word, he said, had Latin roots and had once designated "inanimate beings . . . such as soot, pot, wood, house, \&c," as well as animals. But Walker argued that by 1829 , it had become the purview of U.S. whites who spat it out at "Africans, by way of reproach for our colour, to aggravate and heighten our miseries, because they have their feet on our throats." With this description, Walker signaled that nigger had become a powerful antiblack epithet, whites used it with intention, and its essence could only be illuminated through the use of a violent metaphor. ${ }^{5}$

Even as Walker's definition of nigger held whites solely accountable for its usage, when the word surfaced three more times in the pamphlet, each instance inadvertently revealed that black people used the word too. In one instance, the black abolitionist blurted it after a several-page long diatribe. In his typical radical style, he debunked the prevailing white notion that a black man who sought equality, in truth, wanted nothing more than to pursue a sexual relationship with a white woman. Walker found such a proposition preposterous and, to prove his point, raged that any black man who wanted to marry a white woman "just because she was white, ought to be treated by her as he surely will be, VIZ: as a NIGER[sic]!!!!" At first glance, it seems Walker was simply repeating the language of anti-black whites. If you fetishize whiteness, he declared, you

5. Walker, Walker's Appeal, 61n (emphasis original). 
deserve to be treated as badly as you will. But whether ironically or not, Walker also unabashedly conjured an image of subservience to rebuke black men who sought intimacy with white women. In so doing, he, himself, called those black men niggers. ${ }^{6}$

It might sound jarring to modern ears to hear a nineteenth-century black intellectual use nigger unapologetically, but two final illustrations from the pamphlet show that Walker was not the only person of color to do so. Walker devoted a large section of the provocative manifesto to analyzing the effects of slavery's trauma on African-descended people. He argued that one of the most debilitating aspects of this trauma was that it caused some African American men and women to openly resist a militant strategy for change. These were black folks who Walker dubbed the "ignorant ones;" they were people he believed were satisfied, not with slavery necessarily, but with its legacy, calling themselves "free and happy" in the face of their "wretchedness." In the South they were slaves; in the North, they worked in service to whites without complaint, he thought, shoe shining, barbering, and laundering. To demonstrate this subservience, Walker said he met an enslaved man in North Carolina he quoted as saying, "a Nigar [sic], ought not to have any more sense than enough to work for his master." Walker saw this particular selfnaming as demeaning and obsequious. In an attempt to rectify such ignorance, Walker urged his proselytes to educate black laborers, particularly in the North. He also warned that their conversion would not be an easy one. It seemed, the ignorant ones did not think of themselves as such and instead defied and dismissed other people of color who insisted they were. Walker cautioned, "when you speak to them for their own good, and try to enlighten their minds, [they] laugh at you, and perhaps tell you plump to your face, that they want no instruction from you are any other Niger [sic]. ${ }^{.7}$

In this instance, when the black northerners Walker tried to educate conjured the word nigger, they deployed it as a social leveler. It was as

6. Ibid., 11 .

7. On Walker's argument that the trauma of enslavement had a long-lasting impact on people of color, see Sterling Stuckey, Slave Culture: Nationalist Theory and the Foundations of Black America (New York, 1987), 125-26. On "free and happy," see Walker, Walker's Appeal, 33; and black laborers calling themselves nigger, see ibid., 59; and on calling Walker nigger see ibid., 35n, accessed Dec. $20,2015$. 
if to say, "You are not better than we are." In her study of pre-Civil War New York City, historian Leslie Harris has identified similar instances where African Americans refused to privilege "middle-class, educated blacks and their tactics for racial improvement above more grass-roots political efforts that involved working-class blacks." Like the subjects of Harris's study, black laborers in Walker's Boston similarly refused to assume that there was only one viable strategy for liberation, and they called out Walker and his followers for insisting there was. Still, of all the names they might have called Walker, why did they choose nigger? Moreover, if nigger had been white-only English, why would Walker portray African Americans who spoke it? Ultimately, why would a free person of color rely on language meant to subjugate him? ${ }^{8}$

These questions remain unanswered because, even though David Walker's Appeal offers just one of many instances in which African Americans used the word nigger in the nineteenth century, scholars have yet to fully analyze this practice. The idea that nigger was a seminal antiblack term that gained virulence as a slur in the 1820 s and 1830 s is a fact upon which scholars agree. Cultural theorists such as Randall Kennedy and Jabari Asim and, for the early nineteenth century, historians David Roediger and Patrick Rael, have done marvelous work demonstrating that white northerners became invested in wielding the word precisely at the moment when gradual abolition and emancipation began to free people of color in the North. Moreover, in an important observation, Rael even argues that by the end of the antebellum period middleclass whites and some southern gentleman refused to use the word, not because they were anti-racists, but because they recognized nigger as the vocabulary of the lower classes. If Rael is correct that white people of a certain class felt too superior to utter (or at least to admit to uttering) the word, it seems more likely that their aversion stemmed from African American usage rather than that of vulgar whites. Nevertheless, because scholars have shied away from the discussion, questions remain about the process by which nigger transformed from a harsh descriptor to violent epithet. Perhaps they fear that highlighting black usage might detract from social histories that foreground black agency and resistance. ${ }^{9}$

8. Harris, In the Shadow of Slavery, 5.

9. Kennedy, Nigger, 10-11; Asim, The $\mathcal{N}$ Word, 9-43; Rael, Black Identity and Black Protest, 91-102; and David Roediger, The Wages of Whiteness: Race and the Making of the American Working Class (London, 1999), 19-36. Asim, The $\mathcal{N}$ 
Notwithstanding scholarly reticence on the subject, there is ample evidence to suggest that from at least the eighteenth century, if not before, nigger was a multifaceted and complex part of black English that some people of color, most notably black laborers, used to refer to themselves and other African Americans. That black people spoke the word is substantiated in the sources by the observations of white Europeans who visited the United States in the early nineteenth century. This is a fact that has posed an intellectual problem for scholars because these travelers interpreted black usage as yet another example of servility, obsequiousness, and backwardness. These observers claim to have "frequently" overheard people of color calling out to each other, "you niggar," on southern plantations and in northern cities alike. Each time, the white listener believed she or he had heard an instance of "unbounded insolence and tyranny," or that black people who spoke it were striving to "imitate their superiors." These foreign witnesses asserted that nigger was the vocabulary of white supremacy and that African Americans who used it attempted, however failingly, to cross into a social space reserved for whites. ${ }^{10}$

Scholars, in turn, have tended to interpret the black use of nigger much as the nineteenth-century foreign observers had: African American speakers were simply adopting the language of the oppressor and thus mimicking Anglo American racial conventions in the process. In turn, scholars have glossed over, justified, or condemned this behaviorcalling black usage a sign of affection at its best or of class arrogance or counterrevolutionary ignorance at its worst. In his important book on who can and cannot say the "n-word," Jabari Asim even asserts that

Word, 43. In his thoughtful 2003 essay, historian Walter Johnson argues that it is a historiographical problem endemic of historical writings on slavery that scholars prefer to pursue histories of enslaved peoples when those people's actions can be read as resistance. He argues that such thinking is fundamentally "a mis-posed question: African-American slaves: agents of their own destiny or not?" Walter Johnson, "On Agency," fournal of Social History 37 (Autumn 2003), 113-24, especially $113-16$.

10. Frances Ann Kemble, fournal of a Residence on a Georgian Plantation in 1838-1839, ed. John A. Scott (Athens, GA, 1984), 281; Francis Lieber, The Stranger in America, Or, Letters to a a Gentleman in Germany: Comprising Sketches of the Manners, Society, and National Peculiarities of the United States (Philadelphia, 1835), 90. 
antebellum African Americans who used the word were playing "into the hands of those who opposed their cause." Yet, as the writings of Walker attest, the black use of nigger was more complicated than one simple explanation can neatly convey. Instead of thinking of nigger purely as a word that African Americans borrowed and mimicked from white English, it is more accurate to conceptualize it as a word and a social identity that black laborers ultimately shaped for themselves. ${ }^{11}$

Of course, nigger did not start out as part of African American vocabulary. From at least 1619, when British settlers described the first twenty involuntary black laborers in Jamestown as "Negars," the term emerged as a common colonial descriptor. In British North America, it flattened all African-descended workers into one racialized identity. A nigger was the property of whites, she was black, her bondage was hereditary, and it lasted in perpetuity. A nigger was a slave, a real social category that described an actual class of laborers. When whites used it, it was neither a compliment nor an epithet. It identified a recognizable, albeit degraded, group of workers. ${ }^{12}$

As black freedom began to unfold in the post-revolutionary North, however, the descriptor nigger remained steadfast. This was due in large part to the fact that involuntary labor persisted through the process of gradual abolition under the guise of indentured servitude. Yes, the legislatures of Massachusetts, Vermont, and New Hampshire ended slavery before 1800, but five other northern states-Rhode Island, Connecticut, Pennsylvania, New York, and New Jersey-passed a series of convoluted

11. On the various interpretations of the black use of nigger, see Leon Litwack, North of Slavery: The Negro in the Free States, 1790-1860 (Chicago, 1961), 185-86; Sterling Stuckey, "Through the Prism of Folklore: The Black Ethos in Slavery," The Massachusettes Review 9 (Summer 1968) 427, 80; Asim, The $\mathcal{N}$ Word, 42-43, quote 43.

12. John Smith, The Generall Historie of Virginia by Captain fohn Smith, 1624; The Fourth Booke, ed. John Gardiner Tyler (New York, 1907), 337. The word nigger had several spellings and incarnations, including "negar," "neger," "negur," "negors," and "niger." For a discussion of the fluidity of the word's spellings and pronunciations, see Rael, Black Identity and Black Protest, 91-93. Linguist Geoffrey D. Needler argues that the first use of the modern variant of nigger within the North American colonies (although spelled as "niggor") dates back to 1689, Brooklyn, New York, when the inventory of an estate sale advertised "one niggor boy." Geoffrey D. Needler, "An Antedating of 'Nigger," American Speech 42 (May 1967), 159-60. 
gradual abolition laws that honored the rights of northern slaveholders and did not actually free a single slave. Rather these lawmakers freed the children of slaves, but only after the child served a protracted labor contract. This is a liminal status that historian Joanne Melish aptly calls "statutory slavery." These contracts usually lasted from birth until a person's mid-twenties. ${ }^{13}$

The categories slave and indentured servant were so tightly entangled that some indentured servants found little difference between their own status and that of enslavement. James Mars, an indentured servant from Connecticut who was born to enslaved parents in 1790 and thus technically free, entitled his 1868 narrative Life of James Mars: A Slave Born and Sold in Connecticut. He detailed a life that mirrored the experiences of enslaved people on antebellum plantations including harsh punishments, separation from family, and threat of sale. According to common parlance, someone like Mars would have been referred to as a nigger because, as a black involuntary laborer, he was one. Black intellectuals did not take issue with this casual usage. Walker's angry name-calling suggested that he too recognized nigger as a degraded social class, although he was emphatic that he did not belong to it. In 1837, Hosea Easton, the black minister from Connecticut, also acknowledged that nigger described an actual social category, explaining that "the term in

13. Although Massachusetts, Vermont, and New Hampshire each underwent some form of immediate emancipation, scholars continue to debate what exactly that meant for African Americans living in those states and whether individual slaveholders upheld the laws. See Joanne Pope Melish, who notes that in 1870, the chief clerk of the U.S. census bureau and a Vermonter revised the census record to show 16 people, previously recorded as enslaved, as free. There were also still 157 enslaved people counted in New Hampshire in the 1790 census. Melish ultimately contends that the "immediate freedom" thesis put forth by New Englanders relied more on historical memory than reality. Furthermore, Margot Minardi argues that a legal dispute over Black freedom decided in 1783 and later known as the Quok Walker case did not in fact free all Blacks in Massachusetts as some historians assert. Melish, Disowning Slavery, 64n; Minardi, Making Slavery History: Abolitionism and the Politics of Memory in Massachusetts (New York, 2010), 16-20. For statistics of free Black population in New England, see U.S. Department of Commerce, Bureau of the Census, Negro Population, 1790-1915 (Washington, DC, 1918), 57. On "statutory slavery," see Melish, Disowning Slavery, 88-89. On the legal impact of gradual abolition on enslaved people, see Zilversmit, The First Emancipation, 121-22, 123-24, 128-29, 180-82, 193-94, and 202. 
itself, would be perfectly harmless, were it used only to distinguish one class of society from another." The problem, he argued, was that whites used the word indiscriminately to group involuntary workers such as Mars into a single social category along with black professionals and activists like himself. ${ }^{14}$

Other people of color claimed the word as their own, even as folks such as Walker and Easton bemoaned its use as a single racialized social class. For these African American laborers, at some point during the British North American colonial period, nigger became part of their vocabulary. It was a word that belonged to a group of people who understood that their claims to the United States as a home were impossible, even as they were born, toiled, loved, suffered, struggled, survived, and died within its topography of slavery and violence. It was a viable identification that imagined a community larger than an individual's immediate social networks and extending throughout the Atlantic world and across the diaspora. It is vital to think of nigger as part of a black vocabulary, rather than just a word and a form of violence thrust upon Africandescended people. Doing so helps to explain its vitriol—as opposed to less damaging racialized terms such as "slave," "African," "darky," "black," or "sable." But perhaps even more crucially, understanding the history of the word helps unlock the secret of its undeniable staying power in the vocabulary of African Americans into the twenty-first century. ${ }^{15}$

At the root of both the word's discursive endurance and also its perpetual violence is the fact that in American English nigger diverged and developed more than one meaning, demonstrating how important language was to African American cultural development. In his discussion

14. James Mars, Life of Fames Mars, A Slave Born and Sold in Connecticut (1864; repr. Hartford, CT, 1868), http://docsouth.unc.edu/neh/mars64/menu .html, accessed Dec. 21, 2015. By 1799 when Mars was born, he would have legally been an indentured servant. Nevertheless, he thought of himself as a slave because of his treatment and experiences during the gradual abolition of Connecticut. Easton, A Treatise on the Intellectual Character, 40.

15. In just one helpful example of the many contemporary African American uses of nigger, the Washington Post created an interactive website devoted to this conversation. See "Redefining the Word: Examining a Racial Slur Entrenched in American Vernacular that is More Prevalent than Ever," http://www.washington post.com/sf/national/2014/11/09/the-n-word-an-entrenched-racial-slur-now-more -prevalent-than-ever/. Accessed March 31, 2016. 
of colonial South Carolina, historian Peter Wood argues that enslaved people faced a "trauma of verbal isolation" that encouraged them to quickly acquire a common language in which they adopted some English words, but also retained African ones. Historian John Thornton contends this common language was a lingua franca that fostered commerce and social interaction between people in the Atlantic world of multiple ethnic backgrounds. Even while a broken English allowed for a common mode of communication between African-descended people and sailors, overseers, and slaveholders, nevertheless, as historian Michael Gomez asserts, this language and its vocabulary was never neutral. Gomez contends that when an enslaver forced an enslaved African to "repeat words associated with his captors" and "embrace concepts which further concretized his condition of social death," the enslaved person came to realize that language was, in fact, a political weapon. As an act of subversion, enslaved people responded by making the cadence and meanings of the master's language their own. In this respect, the black use of nigger is just one example of what historian Shane White refers to as black "style." That is, "the process by which objects . . . are taken from dominant culture and given a new meaning in the context of subculture." According to White, one of these objects was language. Thus nigger emerged as a significant part of a lingua franca among African-descended people in the Atlantic world. ${ }^{16}$

As a result of this kind of African and African American cultural adaptation, the word nigger developed with distinctly different meanings depending on the speaker or the conversation. The scope and tenor of these meanings quickly diverged to reflect how Anglo Americans felt

16. Peter Wood, Black Majority: Negroes in Colonial South Carolina (New York, 1974), 170-71; and John Thornton, Africa and Africans in the Making of the Atlantic World, 1400-1680 (Cambridge, UK, 1992), 212-17. The word nigger was part of a transatlantic lexicon, one rooted in slavery and the blending of African, European, and North American cultures and derived from the Latin, Spanish, or Dutch words for "black." On the linguistic etymology of nigger, see Kennedy, "Who Can Say "Nigger??," 86. On black understanding of language as subversive, see Michael A. Gomez, Exchanging Our Country Marks: The Transformation of African Identies in the Colonial and Antebellum South (Chapel Hill, NC, 1998), 167-68, esp. 171-73. On people of African descent using language to express their style, see Shane White, Somewhat More Independent: The End of Slavery in New York City, 1770-1810 (Athens, GA, 1991), 187-92, quotation 187. 
about enslaved people on the one hand and how enslaved people felt about themselves on the other. African Americans built their own meanings around the word nigger, and outsiders found these meanings opaque. The black use of nigger beguiled white listeners. Indeed, African Americans kept the true significance of nigger hidden in plain view. ${ }^{17}$

This is not an attempt to oversimplify the intentions of every black person every time she or he uttered the word nigger. At times, black usage indicated subservience or even class hierarchy. Certainly Walker used it to demean black men interested in interracial marriage. But in other instances, the word nigger disguised a range of complex meanings and intentions: When addressing whites it might signal respect or manipulation or dissemblance; when addressing other African Americans it could signal reproach, but more often it indicated a shared social identity. Indeed, as scholars such as James Scott and Darlene Clark Hine argue, interpreting the "hidden transcript" of a deferent-seeming people necessitates a careful listen to the low hum buzzing beneath the dominant discourse. Consider the possibility that when African Americans spoke the word nigger to each other, they did so to articulate a sense of place within a land that was not their own. ${ }^{18}$

Identifying nigger as a significant part of the vocabulary and cultural identity of black laborers is not simply speculative, but comes from several sources including the writings of black activists, the 1930s WPA interviews of former slaves, and southern and northern slave songs. The most prolific contemporary evidence, however, exists in anti-black cultural productions that gained momentum as a source of entertainment in the North in the late 1770s and 1780s. These pieces mock the black usage of nigger and in so doing demonstrated that whites were disturbed by the practice. As proto-blackface productions, they were the ancestors of antebellum minstrelsy. But unlike the stage performances that became popular in the $1830 \mathrm{~s}$, this blackface was of a literary variety and usually came in the form of letters to the editor in almanacs and newspapers.

17. Herbert Gutman demonstrates how enslaved people could hide their names from enslavers in The Black Family in Slavery and Freedom, 1750-1925 (New York, 1976), 230-37.

18. James C. Scott, Domination and the Arts of Resistance: Hidden Transcripts (New Haven, CT, 1990), 25, 24-34; Darlene Clark Hine, Hine Sight: Black Women and the Re-Construction of American History (Bloomington, IN, 1994), $37-47$. 
Editors of these publications purported either to have received an authentic letter from an African American or one from a bystander who overheard and recorded verbatim an exchange with a white and black person or between two or more persons of color. The satirists who wrote them portrayed African American subjects who were almost invariably masculine, speaking in broken English, belying their slave roots. Since these were caricatured performances, historians such as Shane White and Joanne Melish in their studies of New York and New England, respectively, continue to debate the value of relying on them as a source for real black speech. Whether or not, as scholars argue, the blackface literary productions were authentic renderings of African American speakers or a reflection of an increasingly fixed post-revolutionary racial ideology, they reveal, at the very least, that white Americans were troubled by what the African American use of nigger conveyed. ${ }^{19}$

Each purported letter or anecdote illuminated white anxieties about

19. I focused my analysis on eighteenth- and nineteenth-century newspapers, but it is important to note that Shane White argues that newspapers offer insight into the thinking of mostly urban folks during the period. Almanacs, a source White preferred, were more likely to illuminate rural and non-elite thinking. See White, Somewhat More Independent, 66-69. It might be helpful to note that some of the anti-black humor that White cites in almanacs appeared first in newspapers. For example, White tells of an 1807 anecdote in which an enslaved man named Quash from New Jersey hates hard work and complains "he poor negar man mus worke so hard, and massa do noting." The anecdote appeared earlier in The Daily Advertiser (New York), June 17, 1789. That the joke is repeated twenty years later demonstrates the longevity of the anti-black humor. It also shows how U.S. whites had inserted the word nigger into imaginary African Americans before the nineteenth century. One of the earliest examples of blackface literary production appeared in 1747 in The New York Gazette, which reprinted a supposedly authentic letter sent to a London-based slaveholder from an enslaved man he owned in Herring Bay, Maryland, named "Toby." Writing in broken English, "Toby" told the enslaver, that all was well, except that Sue, presumably an enslaved woman on the plantation, and an old horse were dead. "Toby" signed the letter "from yure oal Negur." From The Maryland Gazette (Annapolis), July 7, 1747, reprinted in The New York Gazette, July 27, 1747. On the uses of broken English in these productions, see Rael, Black Identity and Black Protest, 91-102; Melish, Disowning Slavery, 169-71. On anti-black cultural productions as an historical source, see Melish, Disowning Slavery, 169-71; and White, Somewhat More Independent, 56-75, 187-94; and William J. Mahar, "Black English in Early Blackface Minstrelsy: A New Interpretation of the Sources of Minstrel Show Dialect," American Quarterly 37 (Summer 1985), 260-85. 


\section{Miffer TOMAS}

$$
\text { praput dis in yure papar }
$$

7 be pore negar - I had littel Farm - I fold it I for Fiftie powns - De man who bot it was running way - got Rit for him but Coud not find any. Shirif - caus tha fed thare was not aney in de Cownty - So I lof my Farm-Now I want fum larned Man thud tell $\mathrm{Me}$-wheder de Guverner mult not pa Me-caufe he did not apint a Shirif-I be poer Negar and loft all fo cant give a Lawer aney Mony to tell Me- Io I hop fum larne Man will be cumpahunat ani tell Me-Me tink Guverner thud $p a$ poer SAMBO-

Figure 1: A letter from "Sambo," a "poer Negar," to "Misser Tomas" in the Massachusetts Spy, 1788. Courtesy, American Antiquarian Society.

African American freedom and social mobility in the revolutionary age. The satirists often articulated their fear of black freedom through the incongruous use of the word nigger. On the one hand, the usage signaled the faux letter-writer's obsequiousness. On the other, it drew its black characters as sly and suggested that white listeners were suspicious of the outward subservience of black English, especially given the searing critiques in the letters that addressed topics such as slavery, property ownership, politics, and labor. The following examples all hail from northern newspapers. Therefore, it is important to note that when editors published them, slavery was still practiced in the North. In a letter written to the editor of Worcester's Massachusetts Spy in 1788, "Sambo" described himself as a "poer negar," but he was also a landowner (see Figure 1). Although the satirist attributed the letter to a barely literate man, the subject dealt with how a swindler stole Sambo's property and also how Sambo proposed that the governor of Massachusetts should reimburse him for the theft. Of course, black people had little recourse in the Massachusetts courts and even less of a chance of communicating 
with the governor, so the suggestion itself was part of the humor. At the same time, the very mention of such a gesture hints at the anxiety that whites harbored about the prospect of black freedom, property ownership, and political participation. The anecdote seems to ask: What happens if black people do try to use the system to benefit themselves against the interest of whites? ${ }^{20}$

As literary reenactments of post-revolutionary black identity, these anecdotes served to authenticate a caricature of blackness and of the African American subjects who spoke the word nigger. The satirists imagined black people as innately subservient by coupling the word nigger with the adjective poor, a pointed modifier. In her discussion of white women during the revolutionary period, historian Mary Beth Norton argues that in their letters white women who were facing hard times purposely described themselves in feminized ways. To emphasize their troubles they would identify themselves as "poor" and "helpless," while men in similar dire circumstances self-identified as "unfortunate." In the blackface anecdotes, the use of poor was therefore a decidedly feminizing gesture, one meant to degrade black masculinity. Thus, in a letter published on 4 July 1789, a satirist mollified white fears of black emancipation by having a black subject called "Cuffe" refer to himself and others as "poor negos." This particular article was a facetious response to a report in Philadelphia's Independent Gazetteer. According to Cuffe, a previous article queried how the 600,000 enslaved people in the United States felt about their plight. Signaling how whites believed black people masked their true opinions, Cuffe was unwilling to share his own feelings on slavery, but instead relayed a recent conversation he had with his friend "Pompey." Pompey warned that "by [and] by poor neger kik up a dus" and rise up. Moreover, he said that the abolitionists taught him that the "white man he no right to make slave de poor neger."21

Certainly, part of the message here was that blacks might seem docile, but insurrection was a real possibility. But it also revealed that in the white imaginary, black people's seeming ignorance disguised dubious street smarts, which challenged the social order even as it remained a

20. Massachusetts Spy (Boston), Dec. 11, 1788.

21. On the gender of adjectives, see Mary Beth Norton, Liberty's Daughters: The Revolutionary Experience of American Women, 1750-1800 (1980; repr. Ithaca, NY, 1996), 117. Cuffe's story from The Independent Gazetteer (Philadelphia), July 4, 1789; reprinted in The Norwich Packet (CT), July 17, 1789. 
source of ridicule. In the final analysis, the anecdotes posited African Americans as unintelligible, not simply for their thickly accented speech patterns, but for the sociopolitical identities encompassed by the label nigger that rendered them homegrown foreigners.

Whereas blackface literary productions depicted African Americans who fawningly spoke the word nigger in earshot of white people, when real black people bandied it between each other the tenor was quite different. They did so in recognition of a unifying social identity, one that positioned them as outsiders in white America, but also as part of a viable inside group. One of the most useful nineteenth-century examples of this comes from Harriet Wilson's 1859 autobiographical book, Our Nig; or, Sketches from the Life of a Free Black, In a Two-Story White House, North. Wilson was a black indentured servant during the $1830 \mathrm{~s}$ and 1840s who lived in Milford, New Hampshire, with an abusive white family. Literary scholars argue that the central character of the book, Frado, was Wilson's alter ego, and that the Bellmonts with whom the character Frado lived were likely the family of the abolitionist Nehemiah Hayward, whose wife and daughter brutalized Wilson. According to Wilson's book, when she was six years old, her destitute white mother and equally poor black stepfather signed a contract of servitude, giving the child to the Haywards until she came of age, a process of indenture replicated by other impoverished black families throughout the North. ${ }^{22}$

22. On Wilson and the Hayward family, see Barbara A. White, "Afterword: New Information on Harriet Wilson and the Bellmont Family," in Harriet E. Wilson, Our Nig; Or, Sketches from the Life of a Free Black, In a Two-Story White House, North, Showing That Slavery's Shadows Fall Even There (New York, 2002), iii-liv. Black children found themselves in contracts for indentured servitude when their families were too poor to care for them. Such a fate befell female preachers Jarena Lee, born in New Jersey in the 1780s, and Zilpha Elaw, born in Pennsylvania in the 1790s. Jarena Lee, The Life and Religious Experience of Farena Lee, A Coloured Lady (Philadelphia, 1846); and Zilpha Elaw, Memoirs of the Life, Religious Experience, Ministerial Travels, and Labours of Mrs. Zilpha Elaw, an American Female of Colour (London, 1846); each collected in Sisters of Spirit: Three Black Women's Autobiographies of the Nineteenth Century, ed. William Andrews (Bloomington, IN, 1986), 27 and 53. Ruth Wallis Herndon and John E. Murray call these contracts "pauper apprenticeships." They were often official indentured relationships that impacted the care and work of destitute and/or orphaned children such as Wilson, Lee, and Elaw. Herndon and Murray, "A Proper and Instructive Education': Raising Children in Pauper Apprenticeship," in Children Bound to Labor: The Pauper Apprentice System in Early America, ed. 
At the end of this essay, I will return to Wilson's provocative title, Our Nig, and the multiple, even fractured ways in which she used the word throughout the book. For now, it is enough to note that Wilson's writing offered a rare and sympathetic glimpse into how African Americans spoke to each other. In the initial pages, Wilson imagined a conversation that took place before she was born between her real father, Jim, and his friend and landlord Pete. In the exchange between the two men, Wilson positioned nigger as both neutral and culturally specific. This was emphatically different than how she would later depict her white characters speaking the term. Wilson portrayed Jim as "a kind-hearted African" who was part owner of a business hooping barrels. Jim fell in love with her mother, the fallen and outcast white woman, Mag. One day, Jim was in his workshop and muttering to himself about the prospect of marrying Mag, when Pete, who was also black, startled him. Their exchange went as follows:

Jim: Where you come from, you sly nigger!

Pete: Come, tell me, who is't? Mag Smith, you want to marry?

Jim: Git out, Pete! And when you come in dis shop again, let a nigger know it. Don't steel in like a thief.

This brief conversation demonstrated the easy way that the term nigger fit into the African American lexicon. Jim hollered it to Pete when annoyed, but he also used it to refer to himself. The word could tease, but also express irritation and disdain. The simple interchange revealed a close relationship between the two men, a familiarity. Their use of nigger signaled a mutual recognition of a shared social identity. While Wilson placed a class designation on the word by drawing Jim as unsophisticated and uneducated, she did not give it a negative value, indicating that its meanings were contextual and versatile. ${ }^{23}$

If literary examples provide the richest contemporary evidence of the black use of nigger, the 1930s WPA interviews with former slaves offer

Ruth Wallis Herndon and John E. Murray (Ithaca, NY, 2009), 4-8. As men were more likely than women to acquire positions in manual labor or at sea, more girls than boys served out such pauper apprenticeships. On the gendered nature of black indentured servitude, see Dunbar, A Fragile Freedom, 27-28.

23. Wilson, Our Nig, 9-11. 
the most compelling. The use of the word throughout the WPAs is worthy of further exploration and analysis. Yet, it is certainly anecdotally significant that almost 75 years after the Civil War, nigger remained a viable part of the vocabulary of many of the formerly enslaved. It is tempting to presume that in the WPAs, in which mostly white southerners interviewed former slaves in the Jim Crow South, the black informants used the word nigger to capitulate to white authority. A look at the Virginia interviews, in which most interviewers were African American, however, debunks this theory. Instead, the Virginia WPAs demonstrate that black people spoke the word (during and after enslavement) and imbued it with meanings far more complex than simply mimicking the master's language. For example, Liza Brown casually used it when she described James Harrison's property in land and people, remarking that he "had a gra" big farm an' lots of niggers." On the other hand, after revealing that her father, after far too many beatings, ran away to the woods, former slave Cornelia Carney proudly announced that her father and others were never caught because "Niggers was too smart fo' white folks to git ketched." That enslaved people used the term in complicated ways is exemplified by the words of Mrs. Virginia Hayes Shepherd who remembered that her enslaver allowed so much autonomy among his slaves, that "we were called free niggers by slaves on other plantations." Often African Americans used the word with a distinctly subversive tone, using it in a way that encapsulated the harsh realities of slavery. This was the case when Charles Grandy told the story of how an overseer tried to steal away an enslaved man's wife, and how her husband fought to the death to protect her. Importantly, throughout the story Grandy referred to the husband as a "colored man." But when the overseer wielded a gun and refused to stop shooting until the husband was dead, Grandy relayed, simply and solemnly, "Nigger ain't got no chance." ${ }^{\prime 24}$

The subversive qualities of the black use of nigger are also pronounced in an examination of southern slave songs. Sometimes enslaved people used the word defiantly, announcing their social differences from

24. On African American interviewers in the Virginia WPAs, see Charles L. Perdue, Jr., Thomas E. Barden, and Robert K. Phillips, eds., Weevils in the Wheat: Interviews with Virginia Ex-Slaves (Charlottesville, VA, 1976), xvii-xxvi, 357-59. The quotations belong to Liza Brown, Cornelia Carney, Mrs. Virginia Hayes Shepherd, and Charles Grandy in Weevils in the Wheat, ed. Perdue et al., 63, 67, 117 , and 255. 
U.S. whites. Such was the case with two secular songs that emanate a rebellious tone. In them, the character nigger was drawn as a trickster, a revered (and sometimes notorious) persona in African American folklore for his ability to win small and great victories from the enslaver. This was the same usage adopted by Cornelia Carney when she reflected triumphantly on her father's escape. These songs demonstrate how by using nigger, African Americans could openly get away with scathing cultural critiques of white supremacy and racial slavery. ${ }^{25}$

My name is Ran,

I wuks in the sand,

I rather be a nigger

dan a po' white man

and:

Run, nigger, run, de patrollers will ketch you,

Run, nigger, run, its almost day

Dat nigger run, dat nigger flew;

Dat nigger tore his shirt in two. ${ }^{26}$

While each of the verses highlights a world in which nigger designated containment, neither suggests shame; rather, the word was an open acknowledgement of a shared experience that connected the singer to his audience. In the first verse, the black speaker flouted notions of white supremacy by declaring that he would rather be a slave than an impoverished white person. This was a usage echoed in the Virginia WPAs as when Charles Crawley compared his social condition to that of poor whites, and unflinchingly remarked that "Ole Marster was mo' hard on

25. Lawrence W. Levine, Black Culture and Black Consciousness: AfroAmerican Folk Thought from Slavery to Freedom (New York, 2007), 112-21.

26. Each song is quoted in Sterling Brown, "Negro Folk Expression: Spirituals, Seculars, Ballads and Work Songs," Phylon 14, no. 1 (1st Qtr., 1953), 45-61, see 51. Other slave songs and rhymes confirm that African Americans used the word nigger in this context. For just one example, see Solomon Northrup, "Twelve Years a Slave (1853)," in Solomon Northrup's Twelve Years a Slave and Plantation Life in the Antebellum South, ed. Sue Eakin (Lafayette, LA, 2007), 219-20. 
dem poor white folks den he was on us niggers." The second song juxtaposed the subject's captivity against his surreptitious flight; its rhythm is reminiscent of a somber chant in which still-bound slaves root for the success of a runaway. The African American trickster-who gets away with bold class analysis in the first verse and who takes his freedom in the second-was significant because of the challenge the always-male figure posed to prevailing values. Unlike the "poor nigger" in literary blackface, these chants restored masculinity to the subject. For black laborers the word signaled a flexible discourse that acknowledged the realities of racial identity in the Americas-including containment and servitude-but also bravado and resistance. Nigger was a laboring folk hero, one who defied notions of African American ignorance and subservience, and, was nevertheless called nigger by the people who admired him most. The usage announced that as enslaved and degraded people, African Americans could take their punches, and still develop a meaningful culture. They would make America their own. ${ }^{27}$

African Americans appropriated the word nigger in the United States, eschewing it as a mere labor category and crafting it into a social identity recognized by people of color throughout the North and South. Thus, this self-proclamation was even found in northern slave songs. The following was recorded in Ulster County, New York.

Cold, frosty morning,

Nigger berry good.

Wid his axe on his shoulder,

And way to the wood. ${ }^{28}$

Just as African Americans used nigger as a way to claim a unique identity as involuntary black laborers, whites developed their own version of nigger, the trajectory of which kept pace with the northern transition from slavery to freedom. Significantly, when white northerners used

27. Charles Crawley in Weevils in the Wheat, ed. Perdue et al., 79; and Levine, Black Culture and Black Consciousness, 103-104.

28. Quoted in David S. Cohen, "In Search of Carolus Africanus Rex: AfroDutch Folkore in New York and New Jersey," fournal of the Afro-American Historical and Genealogical Society 5, no. 3 (1984), 157. According to Mrs. Fannie Berry of the WPA interviews with former slaves, this song was also sung in the South. Mrs. Fannie Berry interview, Feb. 26, 1837 in Weevils in the Wheat, ed. Perdue et al., 38 . 
the word, they rarely thought of it as part of their own vocabulary, but instead imagined themselves as quoting, imitating, and ventriloquizing black English. Nigger thus became an accusation that blamed African Americans for speaking the slur, and therefore, for being selfacknowledged niggers. In the early years of black emancipation, the white meaning of nigger expanded to include not just enslaved people, but all free people of color and to flag them as backward and beyond redemption. The word denounced them as people who occupied one immutable, racialized social class, one incapable of achieving real freedom and citizenship. Crucially, the existence of this re-envisioned version of nigger was necessary to define the very essence of what it meant to be white in the post-emancipation North. As historian David Roediger demonstrates, this was particularly true of white laborers in the early national period who began calling themselves "white workers" to highlight the fact that they were " "not slaves' and "not negurs." "The rhetorical separation that rejected the terms "servant" or "master" was a move that both demeaned black laborers and also elevated the word nigger to a term of white working-class empowerment. ${ }^{29}$

In an effort to sustain white supremacy, as the region transitioned to freedom in the $1810 \mathrm{~s}$ and $1820 \mathrm{~s}$, the legacy of slavery increasingly overshadowed all other features of black identity. Whites envisioned African Americans only within a context of their current, former, or imagined enslavement; black people were considered "slave," "free," or "fugitive." Being identified by one's proximity to enslavement carried a special weight in the United States, as Americans predicated republicanism on independence and therefore, as historian Leslie Harris argues, "slaves, as the property of masters, were symbolically and literally the inverse of the ideal republican citizen." People of color not only were not citizens; they were "anti-citizens." Unfettered, African Americans were dangerous to the institution of slavery as insurrectionists and as potential liberators of the enslaved. Free people of color were thus a

29. Quotation is from David Roediger, The Wages of Whiteness, 49. On racial definitions of citizenship, see Roediger, The Wages of Whiteness, 19-92; Matthew Frye Jacobson, Whiteness of a Different Color: European Immigrants and the Alchemy of Race (Cambridge, MA, 1998), 28-31; Evelyn Nakano Glenn, Unequal Freedom: How Race and Gender Shaped American Citizenship and Labor (Cambridge, MA, 2002), 27-36; and Ariela Gross, What Blood Won't Tell: A History of Race on Trial in America (Cambridge, MA, 2008), 16-47. 
distinct threat and, writ large, in need of sequestration as potential menaces to society. ${ }^{30}$

This new, apoplectic version of nigger was more than mere namecalling. By the $1820 \mathrm{~s}$, it threatened real violence, especially to people of color who moved through public space independently. In particular, whites harnessed the word to prevent black geographic mobility and social aspiration. For example, in 1824 at the corner of Pearl Street and Broadway in New York City, three drunken white men attacked the African American owner of an all-night oyster house. When the black man called for the night watch, the three rowdies called out "kill the nigger!" after which one of the drunkards hit the black man on the head with a stone. As with other news items featuring African Americans, the article circulated outside of New York and the reporter crafted the violent episode as comedy. The tag line of the piece made fun of the owner's head injury, asserting that "Ebony felt a fracture in his knowledge box." Demonstrating that such aggression was less fodder for the police blotter than material for the joke section, the incident appeared in a Nantucket newspaper under the heading, "Light Readings." "31

Whites invoked nigger to claim the northern streets as their own and to warn free people of color that the northern public was not their home. Whites summoned the word to vanquish the real black people they harassed and replace them with, in the words of one scholar's apt description of another racialized labor category, "a conglomeration of racial imaginings." In blackface cultural productions, white actors and humorists insisted that nigger was black-only English, depicting African Americans as the sole and original source of the word. Through this

30. Harris, In the Shadow of Slavery, 49; the idea of the anticitizen comes from Roediger, The Wages of Whiteness, 55-57.

31. It is possible that the oyster-house owner in question was Thomas Downing, who went on to become one of the wealthiest black New Yorkers of the period. Downing owned an establishment in the vicinity during the period. See John H. Hewitt, "Mr. Downing and His Oyster House: The Life and Good Works of an African American Entrepreneur," New York History 74 (July 1993), 229-52. The story of the assault of the black business man appeared in The Nantucket Inquirer (MA), May 3, 1824. The story likely originated from Noah's The National Advocate (New York), Apr. 14, 1824, and was then re-circulated in several other newspapers in the region including The Spectator (New York), Apr. 16, 1824; The Salem Gazette (Worcester, MA), and The American Sentinel (Middletown, CT), Apr. 21, 1824. 
process, the portrayals imagined black people as being too ignorant and too servile to know better than to use a word designed to contain them. In a move that is hauntingly similar to the excuses whites give for using nigger in the twenty-first century, in the antebellum period, white Americans absolved themselves of the violence and rancor of the word by insisting that by calling black people nigger, they were simply repeating what African Americans said about themselves. Of course, such an assertion was disingenuous. Whites who verbally assaulted free African Americans with the epithet nigger were not reifying a shared social identity, but instead inscribing black people as un-American. Between whites of all classes, the invocation of nigger was a social contract that united white Americans along racial lines. It was the violent call to arms of regional and ultimately national belonging, and radically different from the word that blacks used among themselves. ${ }^{32}$

That whites reinvented the word nigger as black-only English was a sleight of hand that should not be underestimated. A search of digital databases of nineteenth-century newspapers demonstrates the frequency with which whites attributed the word to African Americans. From the post-revolutionary period and through the 1830 s, editors and letterwriters most often published nigger with quotation marks or italics. They thus attributed the word to black speakers through literary blackface productions similar to the anecdotes that first circulated in the 1770 s and 1780s. For the next half-century of blackface cultural production, white humorists placed the word nigger into the mouths of black caricatures. They did this in order to authenticate black identity. When they were not using it in mockery, they rarely wrote the word at all. ${ }^{33}$

Within these performances, the black use of nigger was a smoking gun of African American backwardness, one that took direct aim at black people who moved through public space. To pose black citizenship as

32. Moon-Ho Jung uses the phrase "a conglomeration of racial imaginings" in his thoughtful definition of the term "coolies" used to describe nineteenth-century Asian immigrants to the United States called "coolies." See Moon-Ho Jung, Coolies and Cane: Race, Labor, and Sugar in the Age of Emancipation (Baltimore, 2006), 5 .

33. On blackface minstrelsy, see Dale Cockrell, Demons of Disorder: Early Blackface Minstrels and Their World (Cambridge, UK, 1997); Eric Lott, Love and Theft: Blackface Minstrelsy and the American Working Class (New York, 1993). 
unimaginable, in hundreds of visual, theatrical and literary cultural productions of the 1820s and 1830s whites used the word nigger as a punch line to underscore racial difference. In one visual example, illustrator Edward Clay sketched a series of broadsides that juxtaposed black strivings against what he saw as a lack of black social etiquette in his "Life in Philadelphia" series. The series was so popular that artists in New York and London emulated Clay in depicting humorous, anti-black broadsides. Presumably the artist observed each of the interactions he mocked in an urban, usually public milieu. Dated circa 1830, plate \# 14 of his collection specifically expressed a gendered anxiety about black upward mobility through the incongruous presence of a black woman, typically burdened by domestic chores, engaging in middle-class pursuits (see Figure 2). In this case, the woman and her male companion were browsing in a milliner's shop at the very moment that Philadelphia was in the process of building a consumer culture; in 1827 merchants built the first mall-like retail structure in the city. The woman's shopping partner was a financially flush African American gentleman called "Frederick Augustus," a grand name for a former slave, and thus a source of comedy. Despite their show of wealth, the couple was outrageously overdressed and so uncultured as to bring a dog into the store. Images such as this one asserted that economic achievement, rather than diffusing African American ignorance, merely afforded black people the resources to become a greater public nuisance. ${ }^{34}$

Significantly, at the same time that Clay's "Life in Philadelphia" series belittled people of color for their social aspiration, it also revealed that African Americans, particularly those in Philadelphia, were developing a well-recognized and formidable political and public culture. Such people posed a considerable threat to prevailing ideas about race and place, and, in the series, Clay's use of nigger was retaliatory against black people

34. For a discussion of Edward Clay, see Rael, Black Identity and Black Protest, 161-73; and Martha S. Jones, All Bound Up Together: The Woman Question in African American Public Culture, 1830-1900 (Chapel Hill, NC, 2007), 18. On the popularity of Clay, see Melish, Disowning Slavery, 172. On black women and domestic work, see Dunbar, A Fragile Freedom, 43-47; Jones, All Bound Up Together, 23-27; and Harris, In the Shadow of Slavery, 98-100. Merchants erected similar retail spaces in Boston (Quincy Market) in 1825 and in New York City in 1829. Stuart Blumin, The Emergence of the Middle Class: Social Experience in the American City, 1760-1900 (New York, 1989), 93. 


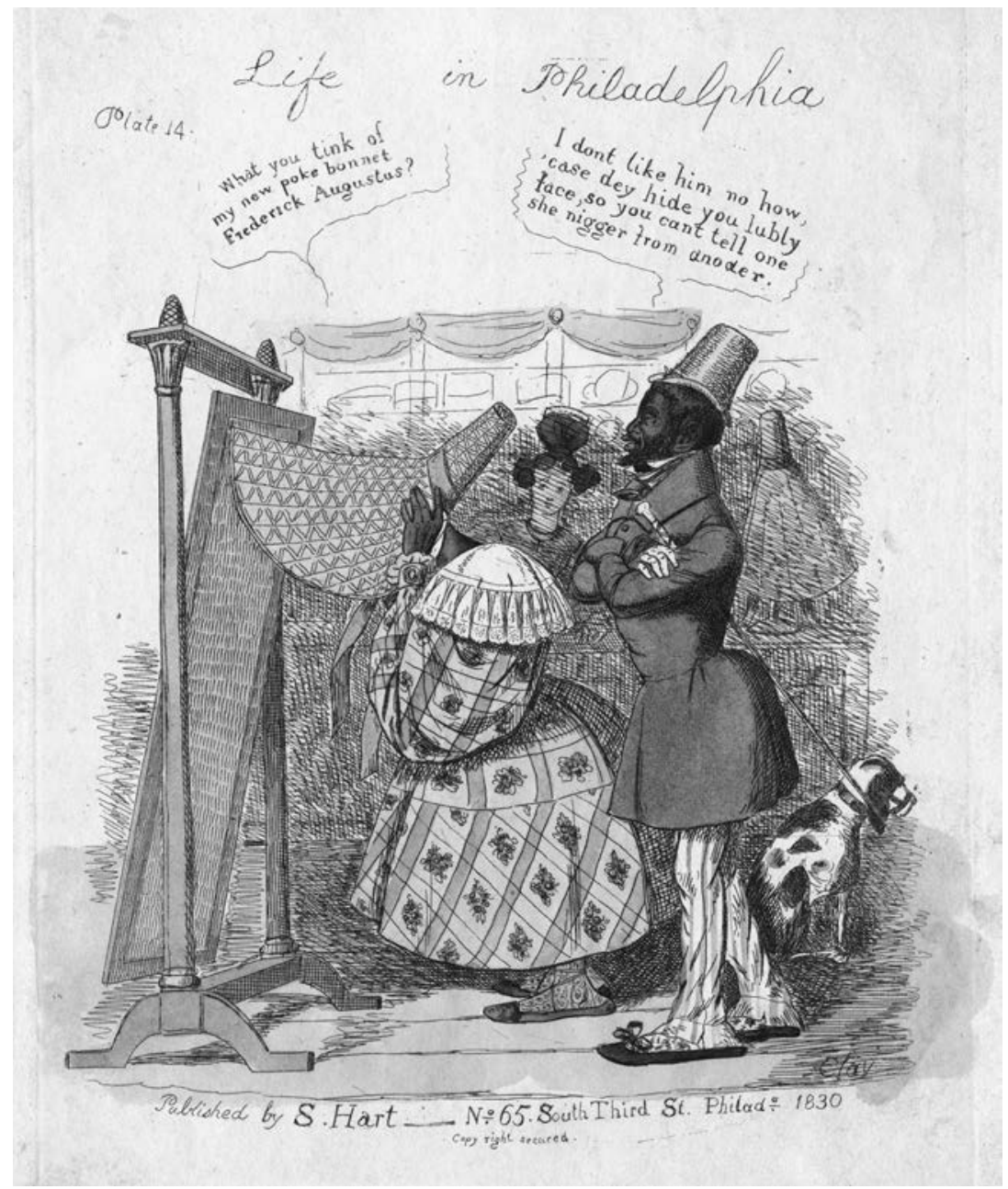

Figure 2: Edward Clay, "Life in Philadelphia," Plate \#14, published by S. Hart, 1830. The Library Company of Philadelphia.

who impeded upon public space. In \#14, the woman asked Frederick Augustus if he liked the oversized bonnet she tried on. He scoffed, "I don't like him no how, [because] dey hide you lubly face, so you cant tell one she nigger from anoder." There are multiple levels to the intended humor here. The caricature played upon the notion of nigger as an inescapable social class by asserting that African Americans were so incapable of individuation that not even a person of color could discern one from another. Most significantly, the commentary challenged 


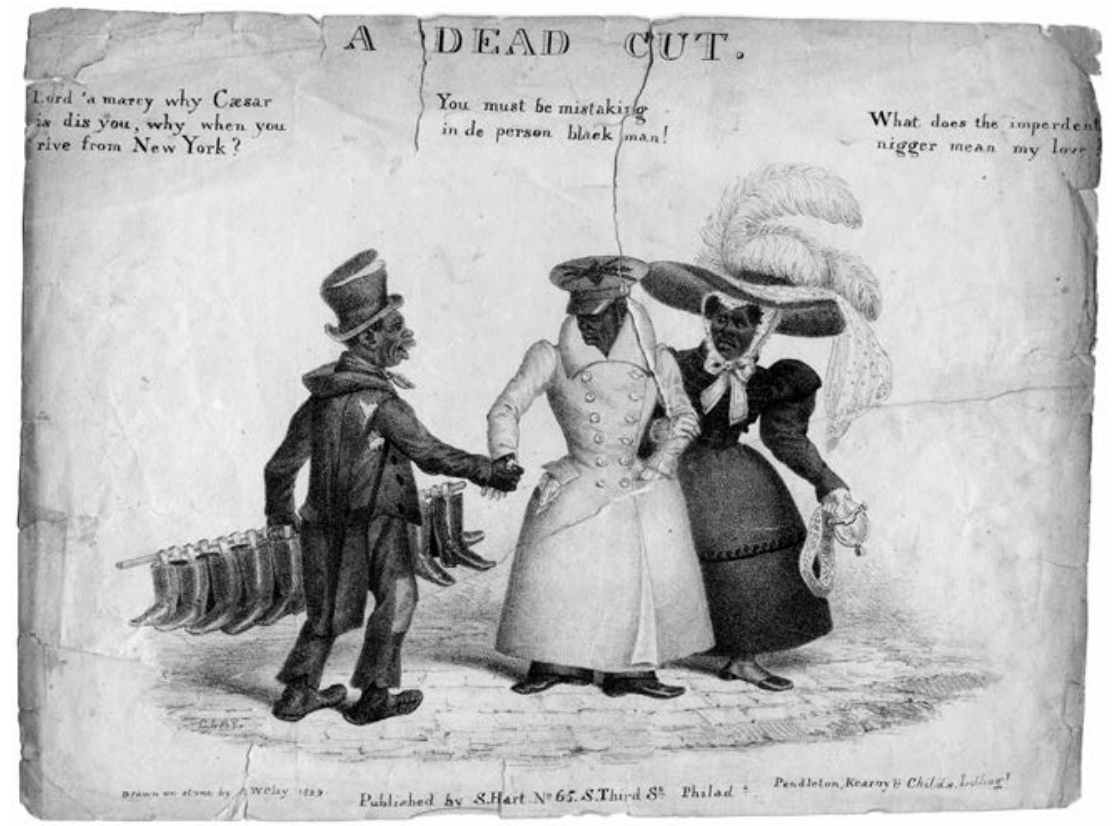

Figure 3: Edward Clay, "Life in Philadelphia: A Dead Cut," published by S. Hart, 1829. Courtesy, American Antiquarian Society.

black claims of masculinity that depended upon the femininity of black women. By having the male figure refer to this woman by the animalizing phrase "she nigger," the caricature insinuated that black men were responsible for contradicting the possibility of black lady-hood. Unable to create the necessary circumstances to allow for the black woman's social elevation, and even disparaging the woman in the process, Frederick Augustus denigrated himself, thus proving that no amount of riches could unmake a nigger. ${ }^{35}$

In another Edward Clay piece from 1829, also from the "Life in Philadelphia" series, the artist used the word nigger to explicitly ridicule the geographic mobility of free people of color, especially those who hoped to vacate the category nigger (see Figure 3). Entitled "A Dead Cut," in this sketch, a bootblack recognizes an old friend, Caesar, a colored traveler who has just returned to Philadelphia after a visit in New York. The

35. Jones, All Bound Up Together, 18-20; E. W. Clay, "Life in Philadelphia" (\#14): What you tink of my new poke bonnet," Aquatint cartoon, 1830, Library Company of Philadelphia. 
depiction mocks the idea that such travel could be transformative for black people as well as any black claims of social and economic aspiration. It also finds its humor by imagining African American class snobbery as ridiculous. When the bootblack shakes hands with Caesar, Caesar refuses to recognize the man. Caesar not only tells him he is mistaken, but insults him by calling him a "black man!" A woman traveling with Caesar, presumably his wife, dressed in an outfit that belies her race and class roots, takes the verbal assault one step further. She asks her husband what the "imperdent [impertinent and impudent] nigger" means. The woman's malapropism, the scope of the racial indictment, and the use of the word nigger are profound. The caricature asserts that not only are black folks silly for even trying to rise socially, but it also accuses the aspirational ones of being the very people who most demean lower class blacks, ostensibly absolving whites for the same. It is antiblack ventriloquism at its finest that had far-reaching impact. Hosea Easton complained that the circulation of broadsides such as this one plastered the windows of popular bookstores, and the ceilings of barrooms and public houses were sometimes "literally covered with them."

Blackface representations lampooned African American social aspiration, but they also cautioned against unrestrained black geographic mobility. This new iteration of anti-black cultural productions was largely a response to black freedom in the North and the interracial abolitionist movement. When African Americans and whites founded the immediate abolition movement in 1831, it garnered a swift and negative reaction. Between 1833 and 1837, white mobs assailed African Africans and white abolitionists across the North, a demonstration of aggression that included 35 riots against abolitionists in the summer of 1835 alone. Anti-abolitionists burned schools, pelted activists with eggs, beat people to a pulp, and shot at least one white abolitionist dead. Anti-black cultural productions joined the anti-abolitionist fervor. The most famous of these was the stage character "Jim Crow." Made famous by white actor Thomas D. Rice, Jim Crow was violent, wild, and at times brilliant, but most significantly, he was a colored traveler who abused his freedom of movement. He crisscrossed the North and South, wreaking havoc along the way. Black sexual desire was palpable in Jim Crow's travels as it was

36. Clay, "Life in Philadelphia: A Dead Cut," 1829, Courtesy, The American Antiquarian Society. Easton, A Treatise on the Intellectual Character, 42. 


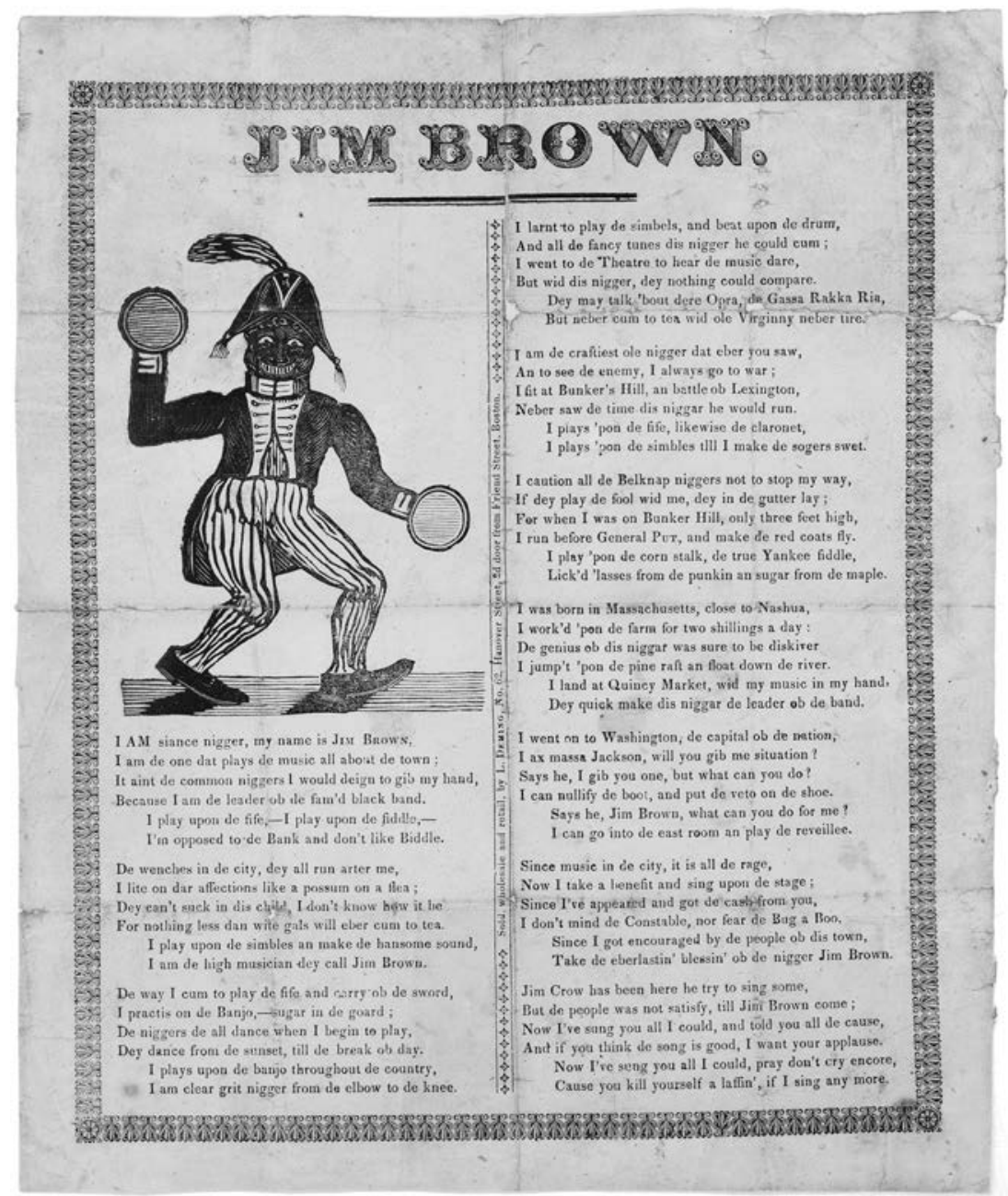

Figure 4: "Jim Brown." This Boston-based rival of Jim Crow traveled from Boston to D.C. bragging about his sexual prowess and threatening other African Americans along the way. He called himself and others nigger throughout. Image is circa 1832-1837. Courtesy, American Antiquarian Society.

with other minstrel characters of the period. Male figures were overtly sexual and full of bravado, and female figures were highly promiscuous and fickle (see Figure 4). This was evidenced in songs such as "The Nigger Wench Fight" or the minstrel opera "Oh Hush" where a bootblack, a wood sawer, a coal scourer, and a chimney sweep all vied for 
the attentions of the "peerless Quasha." According to these performances, African American bodily appetites needed strict regulation. ${ }^{37}$

More daunting still was black male aggression, particularly against other African Americans, an anxiety made more obvious as the minstrel caricatures traversed the nation. Calling his rivals nigger, Jim Crow had a frenetic, primitive need to move, driven by lust, anger, and indiscretion, disrupting public decorum and endangering himself and others in the process. Consider several stanzas from the original Jim Crow song, popularized around 1832:

I went down to de riber, I did'nt mean to stay,

But dere I see so many galls,

I could'nt get away

An den I go to Orleans

An feel so full of fight

Dey put me in de Calaboose,

An keep me dare all night.

$\cdots$

I struck a Jarsey niggar,

In de street de oder day

An I hope I neber stir

If he didn't turn gray.

...

I met a Philadelphia niggar

Dress'd up quite nice \& clean

37. Leonard L. Richards, "Gentlemen of Property and Standing": AntiAbolition Mobs in Facksonian America (New York, 1970), 10-19. Abolitionists called anti-abolitionist violence "the reign of terror." See W. Caleb McDaniel, The Problem of Democracy in the Age of Slavery: Garrisonian Abolitionists and Transatlantic Reform (Baton Rouge, LA, 2013), 53-56; Amber D. Moulton, "Closing the 'Floodgate to Impurity': Moral Reform, Antislavery, and Interracial Marriage in Antebellum Massachusetts," Fournal of the Civil War Era 3 (Mar. 2013), 3-4. For just one contemporary example of the violence, see "Another Mob," The Liberator (Boston), July 23, 1841. The minstrel performances are discussed in Roediger, The Wages of Whiteness, 121; on "Oh Hush," see "The Celebrated Opera of-Oh, Hush," The New York Mirror, Oct. 5, 1833. 
But de way he 'bused de Yorkers

I thought was berry mean

But [Sambo] soon jumped up again,

An 'gan for me to feel,

Says I go away you niggar,

Or I'll skin you like an eel. ${ }^{38}$

As a colored traveler, Jim Crow seemingly moved effortlessly throughout the United States from New Orleans, to New Jersey, to Philadelphia and New York. The innate violence and outlandish sexuality of characters such as Jim Crow ultimately endangered people of color because white audiences actually believed the social aggression enacted on stage was real. The fact that the actors on stage used the word nigger made their portrayals of black violence all the more authentic. In turn, whites could assert their own Americanness by defining themselves against the recalcitrant nigger who chased after women, landed in jail, beat up and even threatened to stab other African Americans. According to onlookers, such uncontrolled African American behavior warranted, even necessitated, white discipline. Under the guise of ventriloquism, whites reenacted anti-black aggression in public spaces and regurgitated nigger in their impromptu performances. In so doing, they sought to eliminate a free black public presence and claim the northern streets as white-only terrain.

Thus, nigger increasingly announced and symbolized the fraught relationship that free people of color had with the United States (see Figure 5). As historian Patrick Rael has meticulously detailed, by the 1830 s, nigger emerged as such a popular epithet that whites even deployed it against other whites to signal the moral and intellectual defects of their ideological enemies. For example, white abolitionists were "nigger lovers" and Republicans were members of the "nigger party." Those Americans who loathed northern emancipation dubbed the region the " "free nigger' North" and New England, specifically, "Free Niggerdom." One white abolitionist proposed a radical strategy of resistance to

38. W. T. Lhamon, Jr., Fump Fim Crow: Lost Plays, Lyrics, and Street Prose of the First Atlantic Popular Culture (Cambridge, MA, 2003), 96-98. 


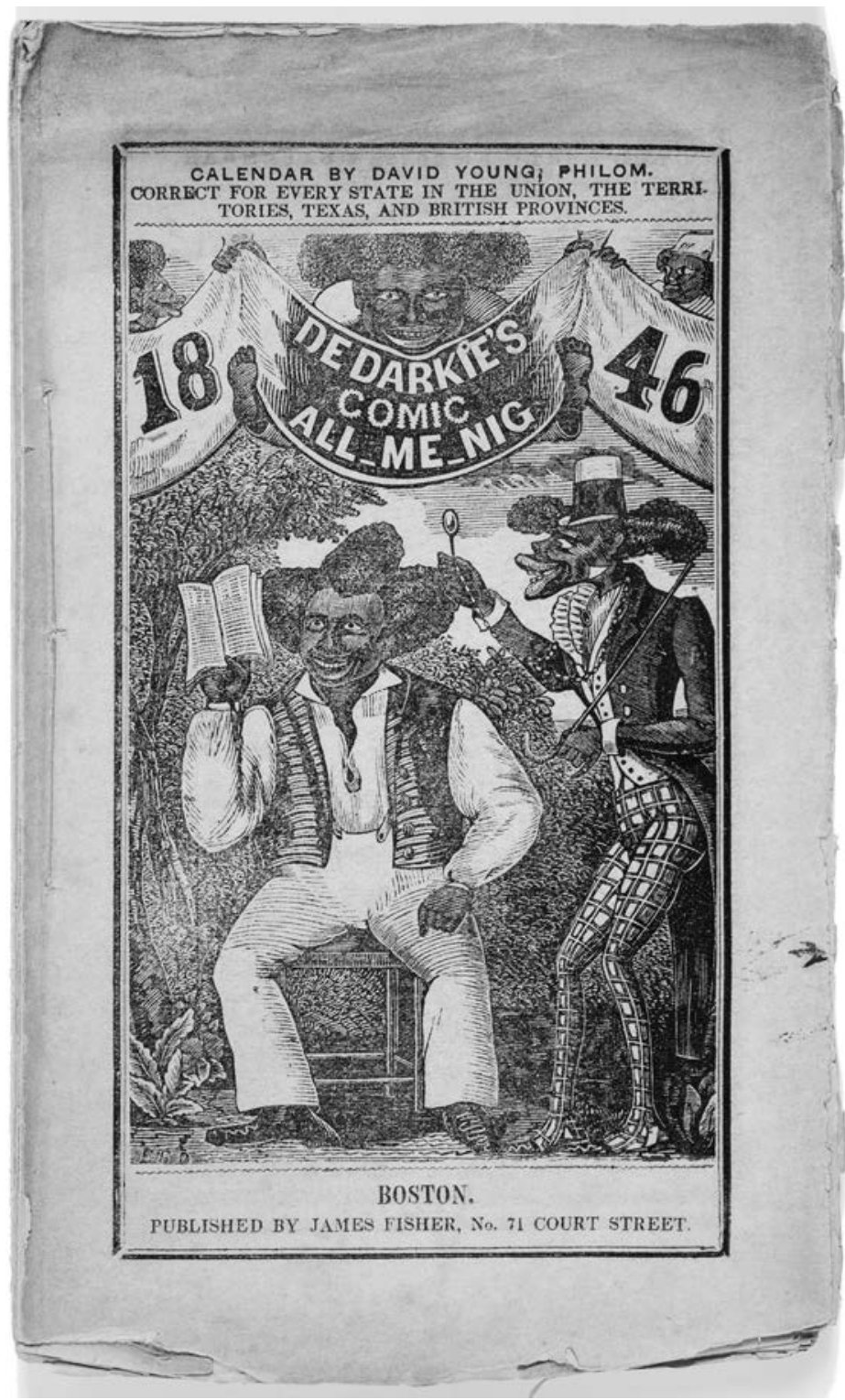

Figure 5: Demonstrating the ubiquity of anti-black sentiment in the antebellum North and its increase in the 1830s and 1840s, this mock-up of an almanac ridicules black dress, style, and habits, but most emphatically indicts the presence of men of color in public space. From the cover of De Darkie's Comic All-Me-Nig (Boston: James Fisher, 1846). Courtesy, American Antiquarian Society. 
such attacks. In the spring of 1839, the editor of New Hampshire's Herald of Freedom, Nathaniel Peabody Rogers, defiantly exclaimed, "Nigger!' 'Nigger!' The hideous epithet is glorious to us. We wear it as a plumage in our crest. We glory in the badge. . . . We covet the appellation. It is full of the deathless honor to abolitionists, but of infamy and condemnation to this land." In order to ameliorate the word's venom, Rogers proposed that [white] abolitionists adopt the term with pride. ${ }^{39}$

Rogers must have quickly found that his African American peers were unconvinced by the strategy of re-appropriation because Rogers soon clarified his position "lest our frequent use of the hated word 'nigger' should have wounded our respected and beloved colored friends." $\mathrm{He}$ explained, "We use the term to put to shame the mean and ungenerous taunters, who continue to cast it on their fellow men. We hope our colored friends will esteem it and use it as we do. It is a weapon for them now to turn upon their unmanly enemies." Notwithstanding his earnest enthusiasm and desire to detoxify the word and the violence that encircled it, Rogers failed to see the reality: As long as anti-black feeling proliferated in the North, nigger would never and could never mean the same thing when spoken by African Americans and by whites. When wielded as an epithet, it would always set the terms of racial inclusion and exclusion. ${ }^{40}$

Unlike with black laborers and even white abolitionists such as Nathaniel Rogers, nigger was not an easy word for black activists to vocalize. Instead, it remained a word that not only denoted race, as the word is understood today, but also invariably class. As early as 1776, a British ex-slave, Ignatius Sancho, who lived in England showed his disdain for the word by describing himself as "one of those people whom the vulgar and illiberal call 'Negurs." Sancho's rejection of the term mirrored his social mobility out of servitude and his class aspiration. As with Sancho, when black activists abandoned the word nigger, they did so as a discursive political strategy that built upon the conscious decision

39. Examples of the use of nigger in politics are quoted in Rael, Black Identity and Black Protest, 98, and also discussed in detail on 91-102. The Pennsylvania Freeman (Philadelphia), Dec. 17, 1838; and also The National Aegis (New York), Apr. 3, 1848. Rogers in "The Herald of Freedom," The Liberator (Boston), July 5, 1839. Rogers had been the editor of the Herald of Freedom (Boston) since 1835.

40. Ibid. 
to create symbolic and intellectual distance between themselves and the condition of enslavement. They discussed nigger publicly not as a unifying status, but as harmful epithet. In the very process of rejecting the word, these activists made their own overt claims to citizenship and social entrée. ${ }^{41}$

The disassociation from the word nigger was in keeping with early strategies for social and political inclusion that hinged on explicitly proving that the categories of black and slave were not interlocked social identities. Starting with a seminal speech made by enslaved New Yorker Jupiter Hammon in 1784, activists sought to combat the negative connotations of enslavement such as immorality, ignorance, and dependence. To do so, they implemented a stringent practice of gender normativity and controlled public behavior, including piety, hard work, and good manners, for the purpose of presenting African Americans as people worthy of citizenship. Far from passive, in lectures, writings, and church sermons, adherents of "moral improvement" emphasized the political significance of respectability when public perception of people of color was dangerously low. For example, in 1837, Samuel Cornish, editor of the African American newspaper The Colored American, grieved that whenever "one of the baser sort of our people commit a crime ... the cry [among whites] is the niggers! the niggers!!" For African Americans, this version of nigger denounced racial difference as a social transgression. ${ }^{42}$

Among African Americans, the speaking of nigger came to denote a person's class. Thus, black writers rarely developed characters who spoke the word. When they did draw such characters, it was meant to highlight the writer's own social elevation. Usually former slaves themselves, these authors depicted the utterance of nigger as the insular vocabulary of people constrained by bondage, but also by a lack of worldly sophistication. As with Harriet Wilson, the word emerged as a marker of class difference among people of color. For example, former slave William Wells Brown's 1853 novel Clotel told a story largely about

41. Ignatius Sancho, Letters of the Late Ignatius Sancho, An African, With Memoirs of His Life by Foseph Fekyll (1802; repr. Freeport, NY, 1971), 70. Stephen Kantrowitz, More Than Freedom: Fighting for Black Citizenship in a White Republic, 1829-1889 (New York, 2012), 28-40.

42. On moral improvement, see Alexander, African or American, 1-2; and The Colored American (New York), Apr. 29, 1837 (emphasis original). 
the tragedy of racial supremacy, wherein he critiqued color consciousness within enslaved communities. In one passage, Brown portrayed a privileged group of slaves who disparaged darker skinned laborers as niggers. In another, a darker skinned worker proudly declared in reference to himself: "Dis nigger is no countefit; he is de genewine artekil." The word was multidimensional; it emitted contempt in one moment and audacity in the next-yet in either case, its usage marked the speaker's lower-class standing. In her 1861 autobiography, self-liberated woman Harriet Jacobs likewise utilized the word nigger to infuse the language of her most provincial black characters in her narrative, Incidents in the Life of a Slave Girl. In just two examples, an enslaved woman "Betty" assisted Jacobs in her 1835 escape, promising:

If dey did know whar you are, dey won't know now. Dey'll be disapinted dis time. Dat's all I got to say. If dey comes rummaging 'mong $m y$ tings, dey'll get one bressed sarssin from dis 'ere nigger. ${ }^{43}$

Later, while awaiting an inspection of the premises by a slaveholder, "Betty" cursed him and his family, saying, "Dis nigger's too cute for 'em dis time." Like the black worker in Brown's novel, "Betty's" use of "this nigger" was a conspiratorial wink to punctuate her autonomy and to indicate her ability to easily outwit the slaveholder. It also marked her as just one member of a larger social identity. ${ }^{44}$

One more example from Incidents helps illustrate the point that class was a paramount factor in the black use of nigger. The character of Linda Brent (Jacobs's pseudonym and alter-ego in the memoir) only uses the word nigger once in the entire book and to pointed effect. To allay her grandmother's fears about the enslaver who relentlessly pursued her and

43. William Wells Brown, Clotel, Or, The President's Daughter: A Narrative of Slave Life in the United States (1853; repr. New York, 1969), 70, 130-36. It is important to note that black writers who wrote black dialogue are not immune from criticism, although one theorist argues that they often did so as a gimmick to attract white abolitionists. Paul Gilmore, "De Genewine Artekil': William Wells Brown, Blackface Minstrelsy, and Abolition," American Literature 69 (Dec. 1997), 743-80; and Harriet A. Jacobs, Incidents in the Life of a Slave Girl: Written by Herself (1861), ed. Jean Fagan Yellin (Cambridge, MA, 1987), 103 (italics original).

44. Jacobs, Incidents in the Life of a Slave Girl, 103. 
to underscore his impotency, Linda assured her grandmother, "The mayor of Boston won't trouble himself to hunt niggers for Dr. Flint." Even though Linda used the word facetiously to dismiss her pursuer, ultimately, Jacobs and other black authors painted nigger as the vocabulary of a degraded social standing and a debased people. These writers acknowledged nigger as a viable social category, but most emphatically one to which they, as free people of a certain social class, did not belong. By thus adopting a politics of respectability, they made their own claims to the United States as home..$^{45}$

Clashes arose when activists imposed their vision of social identity and national belonging on black laborers in the North. Indeed, as the invocation of nigger attests, black workers also had a political consciousness and desired liberation, but did not necessarily believe that an adoption of middle-class respectability would deliver them from their poverty or social ostracism. Most dramatically, conflicts between the classes centered on public behavior and presentations of blackness. Advocates of moral improvement urged "respectable" men not to visit grog shops and "frolics" because public drinking, in particular, was "more ruinous to the lower class of our colour, than any other vice." At the same time, African American laborers pushed back against respectability politics and continued to assert that their own jobs, values, and social identities were valid. An 1827 editorial in the first African American newspaper Freedom's fournal told the story of a black woman, "Mrs. G," who described some black families as snobs who lived beyond their means. Suggesting that some working-class folks saw formal education as a barrier to racial unity, Mrs. G confessed the she found black people aspiring to attain middle-class success to be "too great for me, they have too much learning." Between middle-class blacks and the laboring poor, the speaking of nigger was yet another fault line upon which intra-racial class conflict played out. When black laborers called Walker and his followers nigger, Walker denounced their language as "aggravating."

45. Ibid., 131.

46. Freedom's fournal (New York), July 20, 1827. In her book on black New Yorkers, Leslie Harris argued that although some activists continued to assert that menial labor was inappropriate for a quest to citizenship, others "defended these occupations, claiming dignity for all labor and pride in their own work." Harris, In the Shadow of Slavery, 218-19. The story of Mrs. G in Freedom's fournal (New York), Jan. 9, 1829; and Walker, Walker's Appeal, 35n. 
For elite African Americans, nigger came to signify a concerted assault against free people of color in public space. Therefore, by the late $1830 \mathrm{~s}$, transatlantic black abolitionists began using the word in their writings and speeches to emphasize their growing sense of alienation at home. This was a strategic maneuver meant to lay rhetorical claims to the country of their birth. These black activists exposed the word's vitriol, debunked the frivolity it conveyed in blackface performance and told a community of international abolitionists how nigger encapsulated African American degradation and white supremacy in the United States. In an 1843 lecture before the World Slavery Conference in London, black abolitionist J. W. C. Pennington outlined the myriad impediments that confronted newly freed African Americans in their quest for equality and citizenship. But before he launched into his discussion, Pennington described what he felt was a commonly held belief in "all countries" that free African-descended people were destined to remain niggers because they stubbornly refused to better themselves. He showed the particular dominance of such thinking in the United States by provocatively quoting a stanza he heard from a "Jim Crow" performance: "Do what you will, the nigger will be a nigger still." Lest his international audience believe that such language was only the purview of white workers and not gentlemen, Pennington made plain the multi-class appeal of such cruel prejudice. He confessed that he often heard "from the lips of respectable white people" the following, "Take a nigger, cut off his head, boil him, broil him, throw him into an oven, roast him, he will be a nigger still." ${ }^{\prime 4}$

Reluctantly, Pennington repeated the verses to expose the racism beneath the comic façade of anti-black humor. His examples powerfully detailed the disingenuousness of white racism that accused African Americans themselves for occupying the reviled social status of nigger. He made clear that nigger was not simply a benign word that black laborers used, but a unique American racial profanity. His repetition showed how each childish-sounding rhyme belied a vicious mode of thinking. The verses addressed an invisible white person who exasperatedly tried to dislodge a black person from his slave roots, but to no avail.

47. J. W. C. Pennington, "Speech Delivered at Freemasons' Hall, London, England, June 14, 1843," in The Black Abolitionist Papers, Volume I, The British Isles, 1830-1865, ed. C. Peter Ripley (Chapel Hill, NC, 1985), 106. A similar anti-black rhyme was documented a decade earlier in The Liberator (Boston), Sept. 8, 1832. 
Despite this white person's valiant efforts, an African American was still a nigger. Indeed, under this logic, the social class nigger was not only the fault of people of color, but it was also immutable by black design. Moreover, black people's belligerent poverty and ignorance entitled whites to meet them with aggression. As revealed by the casually cannibalistic language of the second poem, violence crackled around the edges of the accusation nigger. It rendered the black body unsafe from such brutalities as beatings and dismemberment. By insisting that the word was white-only speech and an anti-democratic epithet, Pennington broadcasted its ubiquity, its violence, and the obstruction it caused to African American mobility in his rightful home.

In an effort to situate themselves as a people with legitimate political and social claims to the United States, activists such as Pennington publicly enacted a type of literary and discursive "white face" in which they too ventriloquized the word nigger. Like their white American counterparts, they spoke and wrote the word to quote their enemies, branding it as white-only English. Importantly, the stakes were high for international black activists to speak the word nigger, even for the sake of exposing white racism. By doing so, they chanced being categorized as part of the immutable social class out of which they aspired to rise. Therefore, among early activists, the word was verboten. It did not appear in the first African American newspaper Freedom's fournal that ran from 1827 to 1829, nor was it credited to a black activist in The Liberator until the mid-1830s. The reluctance of early activists to repeat the word brings into stark relief the magnitude of David Walker's use of the word in his 1829 Appeal. When Frederick Douglass traveled to the British Isles from 1845 to 1847, he engaged in a rare instance of using the word casually. He wrote to white Boston abolitionist Francis Jackson that "It is quite an advantage to be a 'nigger' here." He went on to describe that he was not quite black enough for the British, but as long as he kept his hair "wooly," he could "pass for at least a half a negro at any rate." Yet, even as he playfully conjured the familiar pejorative in his letter, he made sure to use quotation marks to indicate that he was quoting U.S. whites and/or racist Britons. ${ }^{48}$

48. I borrow the term "white face" from Marvin McAllister, who likens it to a type of "racial cross dressing." See McAllister, Whiting Up: Whiteface Minstrels and Stage Europeans in African American Performance (Chapel Hill, NC, 2011), 9. A thorough search through Freedom's fournal (New York) for nigger and all its spelling variants turned up no evidence that early activists wanted to incorporate 
By the 1840s, colored travelers such as Pennington and Douglass strategically used the word nigger in their writings and speeches, arguing that in the United States people of color were not somehow uniquely constituted for enslavement and containment. Instead, they asserted that white Americans demeaned and alienated black people through the ideology that nigger represented. Transatlantic abolitionists consistently linked the white use of the word to attacks on black social mobility. In his famous 1845 Narrative, Douglass depicted the word as a representative of racial violence and oppression, demonstrating one memorable instance when his enslaver spewed the word nigger several times to prevent Douglass's education. When Douglass traveled to the British Isles, he passionately detailed how whites in the United States deployed the word nigger to obstruct independent black movement, especially at the thresholds of public space. In a letter from Ireland to white abolitionist William Lloyd Garrison in 1846, Douglass made clear that slavery was not the sole cause of his consistent alienation. He told how in the North both poor and middle-class whites seethed at the prospect of his inclusion in an array of public venues, including steamships, omnibuses, stagecoaches, inns, zoos, and lyceums. Describing the "fiendish hate" he confronted as a man of color attempting to navigate the antebellum North, Douglass repeated nine times the fierce mantra of his white countrymen, "we don't allow niggers in here." 49

Ultimately, black activists made it known internationally that the word nigger and all it represented was a central dictum in the development of African American social identity in the United States, particularly in the North. They reiterated that nigger was what home sounded and looked like. Whether laborers of color incorporated the word into their own vocabulary to signal a shared social experience or middle-class activists brandished it as a sword to fight slavery and prejudice, nigger was a constant companion. Its virulence was a nasty mockery of the culture that people of color built for themselves in the post-revolutionary United

the word into their anti-racism strategies. Similarly, it was not until 1834 that an African American male was quoted as having imitated the epithet nigger in his speech. See The Liberator (Boston), June 28, 1834.

49. Frederick Douglass, "Narrative of the Life of Frederick Douglass, An American Slave (1845)," in Frederick Douglass Autobiographies (New York, 1994), 37. "Frederick Douglass to William Lloyd Garrison," The Liberator (Boston), Jan. 30, 1846 (italics original). 
States. In the 1830s, when blackface cultural productions reached their height of popularity and white parents used nigger as a centerpiece for anti-black instruction, the word gained a violence and omnipresence from which it has never recovered. Nevertheless, when colored travelers used it, they did so to insist that, despite white attempts to exile and banish them, the United States was still their home. They exposed nigger and the sentiment it fostered as impediments to their freedom. By presenting themselves internationally as gentlemen and ladies who reluctantly conjured the word to unmask white racism, they made nigger the verbal symbolic of their ostracism in the country of their birth.

A final word about nigger. Not all African American laborers built a healthy social identity around the black version of nigger, tellingly demonstrating that home remained a dangerous, fraught, and unwelcoming place even after the transatlantic abolitionists traveled abroad. Not all black activists in the North were people who had the opportunity or the resources to escape slavery, involuntary labor, or poverty and thereby transcend the repression of the word nigger. Certainly, only a limited number of activists ever acquired the patronage to travel at all, let alone to foreign shores. For those who reviled the white racism that nigger symbolized but lacked the capital and/or wherewithal to move independently, nigger came to represent their lack of options and the very real fact of their containment. Harriet Wilson was one of these people. Driven by poverty, disability, homelessness, and motherhood, she self-published the book Our Nig to raise money for herself and her child. While the autobiographical work showed how the word signified a shared social identity and offered countless examples of the cruelty and violence of her white characters for using it, more importantly, it demonstrated how nigger was capable of fracturing Wilson's own self. No doubt, the book's title, Our Nig, referenced the Bellmonts' sense of ownership of the child. Yet, in a rhetorical slippage that is repeated throughout the book, the narrator interchangeably called the central character "Frado" and "Nig." For example, when the petulant and violent Bellmont daughter moved away, the narrator commented on Frado's relief, remarking that "Nig went as she was told, and her clear voice was heard as she went, singing in joyous notes." Obviously Wilson utilized the epithet to highlight the horror of her degradation, but in reiterating it, Wilson was also using the word to describe herself. The book's title page emphasizes this. Wilson did not credit the authorship of the book to herself, but instead simply to "Our Nig" (see Figure 6). Whereas the title of the book, "Our Nig," 


\section{OUR NIG;}

or,

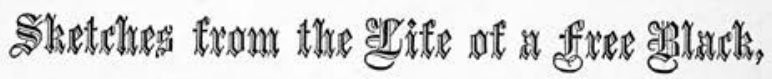

IN A TWO-STORY WHITE HOUSE, NORTH.

SHOWING THAT SLAVERY'S SHADOWS FALL EVEN THERE.

B Y “OU R N I G."

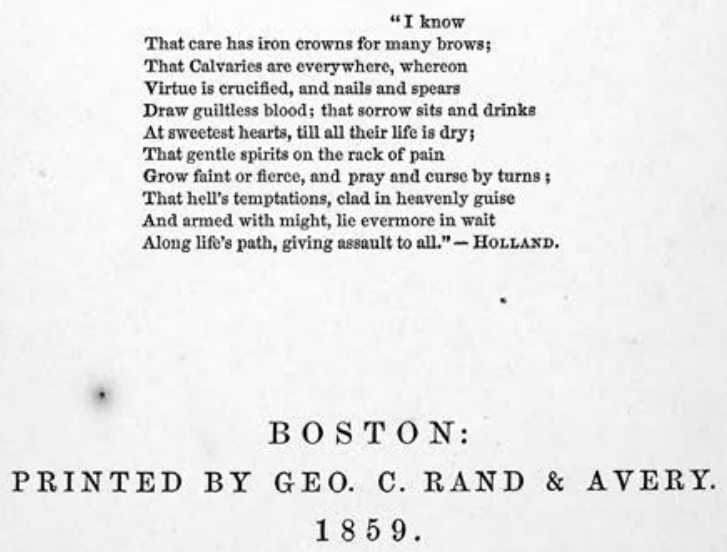

Figure 6: Title Page from Harriet Wilson's Our Nig (Boston: Geo. C. Rand \& Avery, 1859). Mortimer Rare Book Room, Smith College. 
was an obvious indictment of the cruel family that indentured her and the society that allowed it, by calling the author of the piece "Our Nig," Wilson was doing other important work as well. Her anonymity and invisibility here announced a racial alienation that declared, despite her birthright, the white North could never fully be her home. Nor would it ever be to countless more. ${ }^{50}$

50. Wilson, Our Nig, 81. 